Grodno, and some of the provinces bordering on the Vistula. (3) Materials (very meagre) of the White Russian dialect and literature printed in the Reports of the Imperial Academy of Arts, in works published by the Moscow Society of the Lovers of Literature, in the Ethnographical Collection of the Russian Imperial Geographical Society, and the Collections of Chechet and Zenkevitch. Some White Russian songs have been edited by Bezsonov, but I have not seen his book.

I have thus endeavoured to trace the area over which Russian and its dialects are spoken. It will be seen that it is in all respects a vigorous and well-developed language, and I think we may safely prophesy a long future for it. In riches it need not yield the palm to any of its European sisters, and as it relies upon itself, and does not incorporate foreign elements, it may continue to be one of the most independent of modern languages. In the West its progress may be checked, but in the East it is gaining on the Finnish and Tartar tribes, and will no doubt become the language of all Siberia. The dialects will in process of time become absorbed into the dominant tongue; and Russian will thus be the property of about fifty millions. The prospects of such a language can only be paralleled by those of England and Germany.

\title{
XI.-TRADITIONAL RELICS OF THE CORNISH LANGUAGE IN MOUNTS BAY IN 1875. By H. JENNER, EsQ.
}

IN this paper I shall not attempt to discuss the question how far Old Cornish words are still used in conversation by the people of West Cornwall. Such words are undoubtedly used; but they are not known to be Cornish by those that use them, and cannot be said to belong to a tradition of a former language, except in the sense of their having been handed down therefrom. The words with which I have now to deal are not used in conversation, but 
are known, by those who can repeat them, to have formed part of the old language of their ancestors. The words are but few, and almost all of them are known on paper, but they deserve to be put on record as the very last relics of the language that have been handed down by word of mouth without having been incorporated with English.

Some while ago I received information from the Rev. W. S. Lach-Szyrma, Vicar of Newlyn, Penzance, to the effect that he had found in his parish some old people who could repeat the numerals and knew a few other words of Cornish. In July, 1875, I went to West Cornwall, and, in company with Mr. Lach-Szyrma, I visited these old people, and afterwards made an expedition to the little village of Mousehole, in the parish of St. Paul, well known to students of Cornish as the home of the celebrated Mrs. Dolly Pentreath, and, in still earlier days, of John Keigwin. The result of our investigations I have now to put forward. Such as it is, it may be divided into three classes:-A. The Numerals. B. Detached words. C. Three complete sentences.

The names of our informants are as follows:

1. John Kelynack, of Newlyn, fisherman, and his wife, the latter of whom had learnt the words from her father, John Tremethack, who died in 1852, aged 87 (a contemporary, therefore, of Dolly Pentreath, who died in 1778).

2. Mrs. Soady, of Newlyn, a widow of past 80 . She had also learnt of her father.

3. Stephen Richards, of Newlyn, Captain in the merchant service, aged about 70 .

4. Benjamin Victor, of Mousehole, fisherman, aged about 70 .

5. Mrs. Tregarthen, of Newlyn, aged about 60.

A. The numerals.-We obtained two sets of numerals, differing in a few slight points, one from the Kelynacks and one from Mrs. Soady. The best way to show these will be to tabulate them with those given by Dr. Norris in his "Sketch of Cornish Grammar," and by Pryce in his "Archrologia Cornu-Britannica," the latter being those in use in the last century. 
[I have adopted Mr. A. J. Ellis's system of "Glossic" for the spelling of all the words obtained by me. See Appendix. All other words are spelt as I find them in print in the authorities cited.]

\begin{tabular}{|c|c|c|c|c|}
\hline & The KrLYNaOK8. & Mrb. Soldt. & $\begin{array}{c}\text { Prycs. } \\
\text { 18th century. }\end{array}$ & $\begin{array}{c}\text { NoRRIs.' } \\
\text { 16th century. }\end{array}$ \\
\hline $\begin{array}{r}1 \\
2 \\
3 \\
4 \\
5 \\
6 \\
7 \\
8 \\
9 \\
10 \\
11 \\
12 \\
13 \\
14 \\
15 \\
16 \\
17 \\
18 \\
19 \\
20\end{array}$ & $\begin{array}{l}\text { on } \\
\text { doo } \\
\text { trei } \\
\text { paj } \\
\text { pemp } \\
\text { weth } \\
\text { saa'yth } \\
\text { eith } \\
\text { noun } \\
\text { deg } \\
\text { ig·nak } \\
\text { dau'dhak } \\
\text { tan'dhak } \\
\text { bizwau'dhak } \\
\text { pemp'thak } \\
\text { wedh'ak } \\
\text { saa'ydhak } \\
\text { ei-dhak } \\
\text { noun·jak } \\
\text { ig·ung }\end{array}$ & 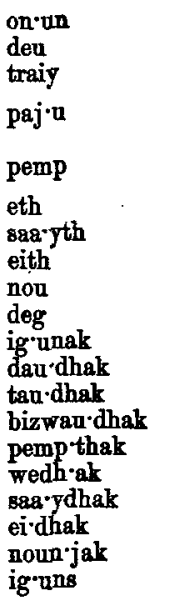 & $\begin{array}{l}\text { wonnan } \\
\text { deau } \\
\text { try } \\
\text { padzher } \\
\text { pemp } \\
\text { wheh } \\
\text { seith } \\
\text { eath } \\
\text { naw } \\
\text { deag } \\
\text { ednack } \\
\text { dowthack } \\
\text { tarthack } \\
\text { puzwarthack } \\
\text { pemdhack } \\
\text { huettag } \\
\text { seitag } \\
\text { eatag } \\
\text { nawnack } \\
\text { iganz }\end{array}$ & 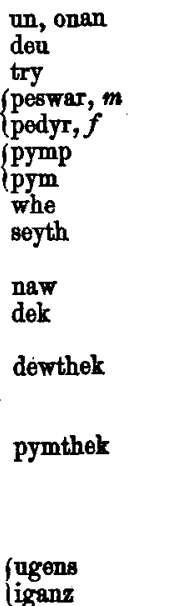 \\
\hline
\end{tabular}

Now this set of numerals is of value in determining the pronunciation of the vowels in the last stage of the language. It would not be difficult to discover from these what Lhwyd, in his "Archæologia Britannica," meant by his elaborate system of Cornish orthography, adopted when the language was actually spoken.

I account for the survival of the numerals on this wise. Pilchards, the great branch of trade in Mounts Bay, are counted in the following manner. Take three in each hand, and say "one," another three and say "two," and so on up to twenty, by which means the "long hundred" (or one hundred and twenty) is arrived at, after which begin again. Now it is easy to see that those who learned English as a

1 In the ceses in which numerals are unrepresented in this column, Dr. Norris has borrowed from Pryce, having failed to find the equivalents in the Cornish dramas. 
new language would find it easier to count in Cornish, and would count their fish in that tongue, and their children would hear them do so, and would do so themselves, and so for that purpose the numerals as far as twenty would survive long after the death of the rest of the language. This, of course, is merely conjectural, for I have no evidence of fish having been counted in Cornish, but the analogies of the mutilated Welsh numerals used in the Yorkshire "sheep scoring," and of the present use of Manx numerals for counting herrings in the Isle of Man by even the Englishspeaking Manx-men, as well as the coincidence of twenty being the limit, give an air of probability to the notion.

B. Detached words.-Some of these were obtained from more than one of our informants. In many of them the rules of changes mentioned at the beginning of my paper on the Cornish Language (Transactions of the Philological Society, 1873-4, p. 165), are noticeably carried out. I have arranged them in alphabetical order, giving to each the name of our informant.

Aaree $u$ (Mrs. Tregarthen).-An expression of surprise. This is the present form of the old expletive re-varia (by St. Mary) mentioned by Scawen (circ. 1670), and by Lhwyd. It is still used occasionally.

Baa gus (Capt. Richards).-A kite or hawk. Baagus vee un a little kite, baa'gus brou a great kite. This word is found in the play of "Origo Mundi" under the form of bargos, in the account of the naming of the animals by Adam. Welsh, barcud, Breton, barced or barged.

Boo.bun (Richards). - A wick for a lamp. The nearest analogy is the Breton poule'ken (méche). As Cornish it is a new word.

Chil (Richards).-A lamp.

Chib.ls (Richards).-Young onions. Welsh, sibrol, Breton, siboles, French ciboule, Italian, cipolla, Latin, cepulla. Not found otherwise in Cornish.

Chei (Richards).-A house. Originally $t i$ or $t y$, under which form it appears in the Cottonian vocabulary and in 
the earlier plays. As a prefix in names of places West of Truro this word (spelt chy) is very common, but in the only instance in which I know of its occurring in East Cornwall (Chytan, near St. Columb), it is sounded chee; but the older form $t y$, which is occasionally found, is sounded (Glossic) $t u$ (as in the name Tyzoardreath). Welsh, ty, Breton, $t i$, Irish and Scotch Gaelic, tigh, Manx, thie.

Deu (Richards, Kelynack and Victor).-Black. Cornish vocabulary (13th century) "duw niger," Welsh, $d u$, Breton, $d u$, Irish and Scotch, $d u b h$, Manx, doo.

Dou $u$ or dow (Richards).-Water. This was given with chei as the meaning of the name Chy-an-dour (a place adjoining Penzance). The vocabulary gives it douer and dofer, Welsh, dior, duofr, Breton, dour, Old Irish, dobhar, ${ }^{l}$ Old Scotch, dobhar (preserved in the word dobhran, an otter), Manx, dubbyr (a pond).

Frag'un (Richards).-Dirt. This was given as the meaning of the name of a field near Newlyn. The Breton frigas, mud, appears to be an analogous word.

Gijoa.ltu (Kelynack and Richards).-A spar used to push out the sail of a fishing boat. Also called a vaagooud. A notched board to keep this in its place was called a timunog $i$ or trimunogi. These words are not used now, and are unknown to fishermen from other coasts, but $I$ can find no derivations for them, though my informants believed them to be Cornish words.

Krog'un (Richards).-A limpet. In the vocabulary this is found as "crogen concha," in which form it also occurs in the Ordinalia and in the Poem of the Passion. Lhwyd writes it crogan. Welsh, cragen, Breton, crogan.

Krou (Richards).-A pigsty. Lhwyd gives this as a hovel, and crow moh a pigsty. The word is still used in West Cornwall, usually in the form "a pig's crow," but is known 
to those who use it as a peculiar word. Welsh, craw, Breton, craou, Irish and Scotch, cro, Manx, croe.

Meenol'as (Kelynack).-A hearth-stone. (Richards and Victor).-A caboose. From men, a stone (Welsh, maen, Breton, men or maen), and ollas, hearth (Welsh, aelwyd, Breton, aoled). This word has a curious history. Kelynack gave it to us as a Cornish word that he had been told of in his youth, and gave its literal meaning; but Victor said that he remembered when a meenol as was used on the fishing boats. It was, he said, a sort of box with stone and clay in the bottom, in which fishermen cooked their food before the invention or introduction of iron stoves. This accounts for the survival of the word. When first used, it was called by the name of the nearest thing to it-a hearth-stone; but since the namers spoke Cornish, they called it meenol as, and, there being no English word for this ingenious makeshift, the original name stuck to it till the thing itself went out of use.

Min'us (Richards).-A small stone used to drive the fish, otherwise known as a kuboo.li-stone. I would conjecture that the original word was men minys, a little stone, and that the word men was dropped.

Peeth (Richards).-A well. This is a new word in Cornish, doubtless from the Latin puteus; Welsh, pydew, Breton, puñs, French, puits.

Pedn (Richards). -A head. Given with names of places. This is the common later form of pen, which is too well known a Celtic word to need discussion.

Vee*un or vee'n (Richards).-Little. This is a common late form of bechan or bikan (with the first mutation). The vocabulary gives it as "bochan parvus," Welsh, bach, and bychan, Breton, bihan, Irish, Scotch and Manx, beg. It is still used in the expression cheeld vee*n or vaiyn = little child (a common vocative), and Mrs. Kelynack remembered a girl who used in her younger days to be called "Jenny vee'un."

The following additional words were supplied by W.J. Rawlings, Esq., of Hayle, who remembered their use many

1 This word, in the form myn olla, is mentioned in a paper by J. H. Nankivell, of Penzance, in the Gentleman's Magazine of September, 1865 . 
years ago. They are undoubtedly Cornish, and, with the exception of the first, are quite obsolete.

Skou or skeu.-An elder-tree. This I have heard used myself, though the impression of the users was clearly that the tree was called a skewo-tree because it was crooked. Welsh, ysgaween, Breton, skaw and scawen, Latin, scobies.

Pun'yun.-A gable. Latin, pinnium, (see Ducange), French, pignon, Welsh, piniun, Breton, piñoun.

Guldaa. $y z$ and diguldaa.yz.-A harvest feast. Lhwyd gives degl as meaning a holiday, and derives it from dedh goil, the day of feast. Welsh, dydd gwyl, Breton, de gouil. The daa.yz is perhaps the English word "tide," with the first initial mutation of $t$ to $d$, and the usual corruption of $d$ to $z$.

C. The Sentences.-1. (Supplied by Kelynack and Richards). Breeül meeŭt (Kelynack met'u) troo'ja bizwau'dhu pem·pez (Kelynack tem'pes) wheth'ez (the rest is English) all ascrowd all along the line oh.-This used to be sung out by fishermen in hauling in the mackerel nets. My informants could not translate it, but Kelynack knew that when they came to the words "all ascrowd," the fish were coming in too thick to count. The translation is this. Bree'ul is a late form of brithel, or as the vocabulary gives it, "breithel mugil," mackerel, from brith, streaked or variegated (Welsh brith, Rreton briz). The Welsh equivalent is brithyll, a trout, and the Breton brezel, mackerel. $M e e^{*} u t$ or met $u$ is simply the English word mate. Troo'ja, bizwau'dhu, pem'pez, weth'ez, are third, fourth, fifth, and sixth. I will just tabulate these with Norris's and Pryce's Cornish, and with the Welsh and Breton.

\begin{tabular}{|c|c|c|c|c|}
\hline $187 \check{5}$. & NoRris. & Prycr. & W RLSE. & Bretoy. \\
\hline $\begin{array}{l}\text { troo'ja } \\
\text { bizwaw'dhu } \\
\text { pem·pez } \\
\text { weth'ez }\end{array}$ & 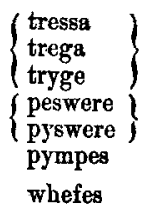 & $\begin{array}{l}\text { trega (g soft) } \\
\text { peswarra } \\
\text { pempaz } \\
\text { wheythas }\end{array}$ & $\left.\begin{array}{l}\text { trydydd } \\
\text { pedwerydd } \\
\text { pummed } \\
\text { \{chweched } \\
\text { chwechfed }\end{array}\right\}$ & $\left\{\begin{array}{l}\text { trived } \\
\text { trede } \\
\text { perarved } \\
\text { pevara } \\
\text { pemved } \\
\text { c'houc'hved }\end{array}\right.$ \\
\hline
\end{tabular}


Kelynack's tem'pez is of course a mistake. The presence of the $d h$ in bizwau dhu is curious. Possibly a form peswarva or peswarves once existed, and the $v$ (as the $f$ in the case of weth'ez changed into th) became $d h .^{1}$

2. Lag'en en dou'u (Richards).-This was explained as meaning splashing backwards and forwards in the water (speaking of fish). Lag'en is probably the same as logan in the name of the Logan (or rocking) stone. It is not Celtic, but seems to have been adopted into Cornish. $E n$ is $i n$. Dou' $u$ is water (see above).

3. Paj;i kulaa tuvee'unpolee'un dumoi'jonaa'y.-This sentence was supplied by Benjamin Victor. His account of it was that it used to be said to an old man called Tom Becaleck, and that it meant "Tom Becaleck, lend me your stick to go to Penzance." The general meaning of this translation is probably right. I think the sentence may be divided in the following way, though two of the words are as yet unintelligible to me.

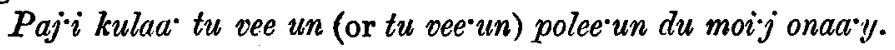

$P a j i$ is pigy or pesy, meaning pray or please.

kulaa I cannot translate-perhaps it means lend.

tu vee is dho vy, to me.

$u n$ is an, the.

(or tuvee'un is do vean, thy little.)

polee $u n$ is similar to the Welsh polyn, a pole or stick.

$d u$ moij $j$ is $d h o$ mos, to go ; the $s$ being corrupted into $j$ according to the common rule.

onaay I cannot translate.

Thus the English of the sentence would be,

Please lend (?) to me the
Please lend thy little stick to go (onaa'y).

This then is the result of our investigations. It is not much, but I believe that there is more to be found. The great district of the Lizard or Meneage peninsula has not been searched yet, but there are several workers in the field,

${ }^{1}$ In Mr. Nankivell's paper, before alluded to, this sentence is given, but with the cardinal numbers from one to six, instead of these ordinals. 
and before long we shall perhaps know for certain exactly how much tradition remains. The outlying districts of Zennor, Morvah and Towednack, in the Land's End peninsula, seem to contain no memories whatever of the old language; but that may be owing to the scattered nature of these parishes, which would have made it difficult for old people to have kept up their knowledge of Cornish by conversing with others of their own age.

Perhaps it may not be out of place here to give a short account of what now remains to be done with regard to the Cornish language before every remaining fragment of it is carefully put into print.

1. There are several proverbs, songs and sentences of late Cornish to be found in the Gwavas MSS. (Add. 28,554) in the British Museum, and in the MSS. of Dr. Borlase at Castle Hornick, Penzance. These should be printed and annotated, and such of them as have been already printed by Pryce and Davies Gilbert should be done over again, as those editions, especially the latter, are almost worthless.

2. Then a supplement should be made to the excellent Cornish Lexicon of the Rev. Robert.Williams, which should contain every word or form of a word (not already recorded therein) that is to be found in the aforesaid MSS., in Andrew Borde's Cornish dialogues in his "Boke of the Introduction to Knowledge," in Symonds' diary of the Civil War, in Richard Carew's "Survey of Cornwall," in the Drama of St. Meriasek, and even (with judicious selection) in Hals' History of Cornwall. No one could do this better than Canon Williams himself, if his valuable work in the way of editing Welsh Romances should leave him time to undertake it.

3. Lastly, perhaps a grammar should be made, based upon Dr. Norris's "Sketch of Cornish Grammar," and that in Lhwyd's "Archæologia Britannica," only bringing in every period of the language.

When these things are done, one at least of the world's languages will have been thoroughly worked out. 


\section{APPENDIX.}

Tabie of Glossto Letters used in the Foregotng Paper. vowBLs.

A As $a$ in bat.

AA As $a$ in father.

$A A \cdot Y$ As the word aye (meaning yes), broadly sounded.

$\mathrm{AI} \cdot \mathrm{Y}$ As ay in tray.

$\mathrm{AU} \quad \mathrm{As}$ aw in law.

E The ordinary short $e$, as in men.

EE The ordinary long. $e$, as ee in seen.

EE- $\breve{u}$ A fracture of the preceding, as in the word ear with the $r$ perfectly untrilled.

\section{EI As $y$ in $m y$.}

EU As ero in dero.

I As $i$ in tin.

$0 \quad$ As $o$ in not.

$\mathrm{OA} \quad \mathrm{As} o$ in smoke.

OI $A s$ oy in boy.

OO As oo in pool.

$00 \cdot \breve{u}$ A fracture of the preceding, as oor in moor with the $r$ untrilled.

OU As ow in now.

U Common short $u$ as in until, or like the second $e$ in the German meine.

The consonants have their usual English value. The following only call for any remark. $C h$ is always soft, as in church. $G$ always hard, as in go, get. $J$ always sounded, as in James. $D h$ represents $t h$ as in thy, th being always sounded as in thin.

For more minute description of the value of Glossic letters, and for their comparison with Palæotype and with Mr. Melville Bell's Visible Speech letters, see the Appendix to Mr. Elworthy's paper on the West Somerset Dialect in the Transactions of the Philological Society for 1875-6, Part I. pp. 218-272. 